\title{
Validation of Intructional Learning Based on M-APOS Approach to Improve Students' Reasoning
}

\author{
$1^{\text {st }}$ Hayati Nufus \\ Department of Mathematics \\ Universitas Negeri Padang \\ Padang, Indonesia \\ hayatinufusbundaraihan@gmail.com
}

\author{
$2^{\text {nd }}$ Yerizon \\ Department of Mathematics \\ Universitas Negeri Padang \\ Padang, Indonesia
}

\author{
$3^{\text {rd }}$ Armiati \\ Department of Mathematics \\ Universitas Negeri Padang \\ Padang, Indonesia
}

\begin{abstract}
The purpose of this research is to develop the instructional learning based on M-APOS approach to improve students' reasoning abilities valid. This research is a development research. It is consists of three stages: the initial investigation stage, development stage, and assessment phase. The result of the development stage is a valid instructional learning according to experts. They are three mathematicians, one language expert, and one technology expert. The validity of instructional tools is based on the following aspects: 1) the didactic aspects (presentation); 2) content feasibility aspects; 3 ) language aspects; and 4) the graphic aspects. The validation result of instructional learning are 1) the didactic aspects (presentation) 3.59 (very valid), 2) content feasibility aspects 3.56 (very valid),3) language aspects 3.00 (valid), 4) the graphic aspects 4.00 (very valid).
\end{abstract}

\section{Keywords-M-APOS, Validation, Reasoning Capability}

\section{INTRODUCTION}

This Mathematical reasoning ability is very important in achieving the goal of learning mathematics learners. In mathematics learning is not only to improve and change the facts and skills, but more emphasis on the importance of assuming, communicating, solving problems and logical thinking. This is because learning mathematics not only studies it as a fixed and unchanging set of facts and skills, but it should be an emphasis on the importance of conjecturing, communicating, problem solving and logical reasoning [3].

Reasoning is a mental process in developing the minds of some fact or principle [2]. Based on the Big Indonesian Dictionary, reasoning is: (a) the way (about) using the flow, thinking or logical thinking; range of thinking; (b) Things that develop or control things with reason and not with feelings or experiences; (c) mental processes by developing thoughts from several facts or principles. One of the objectives of learning mathematics based on the Minister of Education and Culture Regulation No. 58 of 2014 in point 2, which is using patterns as a guess in solving problems and being able to make generalizations. It can be concluded that reasoning is an activity or activity to draw a conclusion or a new statement that is found by connecting the facts given to solve the problem and make a generalization.

To achieve improved reasoning abilities required its learners learning device. Learning devices become a handbook for teachers in learning implementing in the classroom, laboratory or outside the classroom. Device learning device is a tool or equipment to carry out the process that will enable educators and learners perform the learning activities [9]. In this study, the learning device developed using M-APOS theory approach. M-APOS is modification of APOS (Action, Process, Object and Scheme). APOS theory developed by Dubinsky, consists of Action, in which participants conduct various activities from the teacher, the process by which the participants take repeated actions, the things that the participants do from the process carried out Make a lesson from students Keywords: actions, actions, actions, objects that students do in the learning process. The learning tools developed need to be validated so that the device can be used for learning, validation of two uses of validity, construct validity.

Validity refers to the accuracy of an instrument for measuring what is desired [8]. The validity of the content is the need for intervention (devices made), and the design is based on scientific knowledge [7]. While designing interventions construct validity (the learning device) in accordance with the logic/ reason right (logical). With the Mtheory based learning valid APOS can improve mathematical reasoning abilities of learners.

\section{METHODS}

The method in this research is the development method using a questionnaire validation to some of the experts. Three mathematicians, linguists one person, one person technology experts. The validity of the learning device from the aspects of: 1) the didactic aspect (presentation), 2) feasibility aspects of content, 3) language aspects, 4) aspects of the graphic.

Determining the value of the validity of the learning device by using the formula proposed by Muliyardi is as follows [5] :

$$
R=\frac{\sum_{j=1}^{m} \overline{x_{j}}}{m}
$$

Information:

${ }^{R}=$ Validity learning device

$\overline{x_{J}}=$ Average validity of the assessment results to the item-j $m=$ Sum of items

Interpretation of the validity of the learning device is determined by the following criteria [6]: 
TABLE I. CRITERION VALIDITY OF LEARNING TOOL

\begin{tabular}{|c|c|}
\hline Criteria & Interpretation \\
\hline $\mathrm{R} \leq 0.08$ & Invalid \\
\hline $0.08<\mathrm{R} \leq 1.60$ & less valid \\
\hline $1.60<\mathrm{R} \leq 2.40$ & enough valid \\
\hline $2.40<\mathrm{R} \leq 3.20$ & Valid \\
\hline $\mathrm{R}>3.20$ & very valid \\
\hline
\end{tabular}

\section{RESULT AND DISCUSSION}

Valid devices can be used if aspects of the indicator can be used for anything. Validation of the learning device carried by five experts among its Three mathematicians, linguists one person, one person technology experts. The results of the validation of the device by the experts:

1. Validity RPP

\begin{tabular}{|c|c|c|c|}
\hline No. & Rated aspect & Average & Category \\
\hline 1 & Subjects Identity & 4 & very valid \\
\hline 2 & $\begin{array}{l}\text { Basic Competency } \\
\text { (KD) }\end{array}$ & 4 & Very valid \\
\hline 3 & $\begin{array}{l}\text { Learning Indicators } \\
\text { Formulation }\end{array}$ & 3.4 & very valid \\
\hline 4 & $\begin{array}{c}\text { Formulation of } \\
\text { Learning Objectives }\end{array}$ & $3: 43$ & very valid \\
\hline 5 & $\begin{array}{c}\text { Selection of learning } \\
\text { materials }\end{array}$ & $3: 12$ & valid \\
\hline 6 & $\begin{array}{c}\text { Selection of learning } \\
\text { strategies }\end{array}$ & $3: 16$ & valid \\
\hline 7 & $\begin{array}{l}\text { Selection of Learning } \\
\text { Resources }\end{array}$ & 2.75 & valid \\
\hline 8 & $\begin{array}{c}\text { Selection of } \\
\text { Instructional Media }\end{array}$ & $3: 25$ & very valid \\
\hline \multirow{4}{*}{9} & \multicolumn{3}{|c|}{ Steps Learning Activities } \\
\hline & Preliminary activities & $3: 14$ & valid \\
\hline & Core activities & $3: 13$ & valid \\
\hline & The activities cover & $3: 08$ & valid \\
\hline 10 & appraisal & $3: 12$ & valid \\
\hline 11 & Language and writing & 3 & valid \\
\hline 12 & Benefit RPP & 3.5 & valid \\
\hline
\end{tabular}

2. The results of the validation LKPD

\begin{tabular}{|c|c|c|l|}
\hline No. & Aspect & Average & Category \\
\hline 1. & didactic & 3.59 & very valid \\
\hline 2. & Material or Content & 3.56 & very valid \\
\hline 3. & Language & 3.00 & valid \\
\hline 4. & Graphic & $4: 00$ & very valid \\
\hline \multicolumn{2}{|c|}{ Average } & $\mathbf{3 . 5 4}$ & very valid \\
\hline
\end{tabular}

Results of the RPP and LKPD validity of some of the experts, it can be said that the RPP and LKPD that use MAPOS theory approach is valid and can be used in the learning process. It is expected that with a valid learning devices will be able to improve mathematical reasoning abilities of learners, so that mathematics learning objectives can be achieved.

\section{CONCLUSION AND RECOMMENDATION}

From the above, it can be concluded that the learning tools that will be used in this study was valid. The validity of the RPP can be seen from 12 aspects, as well as the validity LKPD seen from four aspects (didactic, material/ content, language, graphic). Results of the validity of the RPP and LKPD very valid..

\section{REFERENCES}

[1] Dubinsky. E., "The APOS theory of learning mathematics: Pedagogical applications and results", Paper presented at the Eighteenth Annual Meeting of the Southern African Association for Researchin Mathematics, Scienceand Technology Education, Durban, SouthAfrica, January, 2010.

[2] Herdian, "Kemampuan Penalaran Matematika", (online), (http://hardy07.wordpress.com/Kemampuan-Penalaran-Matematis) 2010.

[3] Mudrikah. Ahmad, "Problem-Based-Learning Associated by ActioObject-Proces-Schema (APOS) Theory to Enhance Student's High Order Mathematical Thingking Ability", International Journal of Research in Education and Science (IJRES), 2(1), 125-135, 2016.

[4] Muliyardi, Strategi Pembelajaran Matematika. Padang: UNP, 2002.

[5] _Pengembangan Media Pembelajaran Matematika Berbasis $\overline{\text { Komik }}$ di Kelas I Sekolah Dasar", Disertasi tidak diterbitkan, Surabaya: UNESA, 2006.

[6] Permendikbud Nomor 58 Tahun 2014, Standar Isi Pendidikan Dasar dan Menengah, Jakarta : BSNP.

[7] Plomp. T., \& Nieveen. N., (Eds.), "Educational design research: Illustrative cases" Enschede, the Netherlands: SLO, 2013, (free access at www.international.slo.nl) (accessed 18 August, 2017).

[8] Sukardi, Evaluasi Pendidikan. Jakarta: BumiAksara, 2008.

[9] Zuhdan. dkk., "Pengembangan Perangkat Pembelajaran Sains Terpadu Untuk Meningkatkan Kognitif, Keterampilan Proses, Kreativitas serta Menerapkan Konsep Ilmiah Peserta Didik SMP”, Program Pascasarjana UNY, 2011. 